\title{
Article
}

\section{Providing Alternatives to Infant Institutionalization in Bulgaria: Can Gatekeeping Benefit from a Social Development Orientation?}

\author{
Bilson, Andy and Larkins, Cath \\ Available at http://clok.uclan.ac.uk/8454/ \\ Bilson, Andy and Larkins, Cath ORCID: 0000-0003-2999-6916 (2013) Providing \\ Alternatives to Infant Institutionalization in Bulgaria: Can Gatekeeping Benefit \\ from a Social Development Orientation? Children and Youth Services Review, \\ 35 (9). pp. 1566-1575. ISSN 0190-7409
}

It is advisable to refer to the publisher's version if you intend to cite from the work. http://dx.doi.org/10.1016/j.childyouth.2013.06.008

For more information about UCLan's research in this area go to http://www.uclan.ac.uk/researchgroups/ and search for < name of research Group>.

For information about Research generally at UCLan please go to http://www.uclan.ac.uk/research/

All outputs in CLoK are protected by Intellectual Property Rights law, including Copyright law. Copyright, IPR and Moral Rights for the works on this site are retained by the individual authors and/or other copyright owners. Terms and conditions for use of this material are defined in the policies page.

\section{CLoK}

Central Lancashire online Knowledge www.clok.uclan.ac.uk

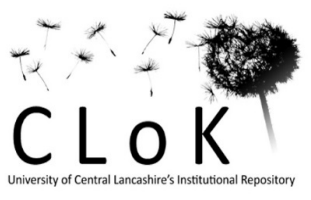




\section{Accepted Manuscript}

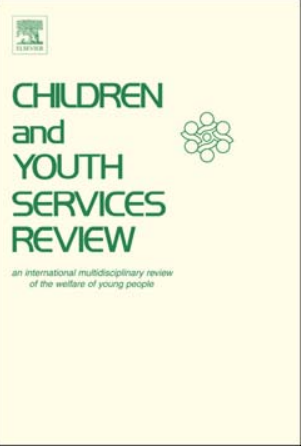

PII:

S0190-7409(13)00224-7

DOI: $\quad$ doi: $10.1016 /$ j.childyouth.2013.06.008

Reference: $\quad$ CYSR 2202

To appear in: $\quad$ Children and Youth Services Review

Received date: 13 December 2012

Revised date: $\quad 15$ April 2013

Accepted date: 9 June 2013

Please cite this article as: Bilson, A. \& Larkins, C., Providing Alternatives to Infant Institutionalisation in Bulgaria: Can Gatekeeping Benefit from a Social Development Orientation?, Children and Youth Services Review (2013), doi: 10.1016/j.childyouth.2013.06.008

This is a PDF file of an unedited manuscript that has been accepted for publication. As a service to our customers we are providing this early version of the manuscript. The manuscript will undergo copyediting, typesetting, and review of the resulting proof before it is published in its final form. Please note that during the production process errors may be discovered which could affect the content, and all legal disclaimers that apply to the journal pertain. 


\section{Providing Alternatives to Infant Institutionalisation in Bulgaria: Can Gatekeeping Benefit from a Social Development Orientation?}

\section{Authors}

Andy Bilson corresponding author

School of Social Work, University of Central Lancashire, Preston PR1 2HE, UK Mobile +447976069387

Emails abilson@uclan.ac.uk and andy@bilson.org.uk

Cath Larkins, Senior Researach Fellow

School of Social Work, University of Central Lancashire, Preston PR1 2HE, UK

Tel: $\quad+447787892246$

Email: clarkins@uclan.ac.uk 
Abstract: There is extensive research demonstrating the negative effects of institutionalisation on infants. Gatekeeping has been widely promoted as a key strategy to combat unnecessary institutionalisation. Its aim is to provide a range of services and a system of decision making based on assessments of children and families to ensure effective targeting of services. This paper provides details of research into the gatekeeping system in Bulgaria for children under three and examples from recent Bulgarian and international practice. It suggests that gatekeeping could benefit from a social development orientation including activities to combat poverty and promote social inclusion through supporting community and family strengths. The paper proposes changes to the orientation of gatekeeping for effective national strategies to combat institutionalisation. 


\section{Introduction}

There continues to be a large number and growing rate of infants in institutional care in a number of countries, particularly those that were formerly under soviet control. This contravenes a range of UN and European human rights standards and there is also extensive evidence of the poor outcomes of children aged three years and younger (Bilson 2010). On $28^{\text {th }}$ June 2011 the Office of the High Commissioner for Human Rights and UNICEF made a joint call for action to end placing children under three in institutions.

The joint call to action follows on from previous work aimed at reducing rates of infant institutionalisation in countries formerly part of the Soviet Union. In 2000 the World Bank and UNICEF's Changing Minds, Policies and Lives project aimed to advise governments in Central and Eastern Europe and the Commonwealth of Independent States (CEE / CIS) on strategies to reduce the use of institutionalisation. It proposed gatekeeping as a central element of this strategy, along with developing standards for children's services and advice on the transfer of resources from the institutional sector into community based services. Gatekeeping was defined as "the system of decision making that guides effective and efficient targeting of services" (Reichenberg \& Posarac, 2003: vi in Bilson and Harwin 2003). Bilson \& Harwin (2003) produced a toolkit on gatekeeping as an outcome of this project and this has been widely disseminated and used by governments in CEE / CIS (see for example Gudbrandsson, 2004; EveryChild, 2007; Holiček, Severinsson \& Reichenberg; 2007).

This paper will use data from Bulgaria, part of a wider study of three countries, to consider the effectiveness of gatekeeping for children under three entering or remaining in institutions in a country where the government has made a commitment to close all its large institutions and is currently planning the closure of seven institutions for infants. It will go on to use what has been learnt from recent institutional closures and promising practices across CEE/CIS to suggest that a social development orientation within the framework of gatekeeping reflects current good practice and might provide a basis for challenging the values that lead to separation of children from parental care and respond more effectively to underpinning problems of social exclusion and poverty.

\section{Methods}

The study in Bulgaria, Kazakhstan and Ukraine (Bilson, 2010) considered a range of groups at risk and children without parental care including: children with disabilities, child victims of abuse and children in conflict with the law. It aimed to discover how children enter and remain in institutional care; whether gatekeeping was being implemented; and if gatekeeping was sufficient to prevent unnecessary institutionalisation. 
It included a detailed desk review of: laws and regulations; national strategies; action plans; other documentation relating to routes into care; institutional and financial mechanisms; human resources; and social care standards. The information available at a national level was often patchy or non-existent and this was supplemented by studies of a small number of institutions. Field research was then undertaken to review gatekeeping mechanisms and other factors relating to institutionalisation. Field visits were each around 10 working days using a rapid assessment procedure (Pearson \& Kessler, 1992) involving interviews and meetings with stakeholders, including professionals fulfilling gatekeeping functions, working in and for NGOs plus civil society representatives, judiciary, and parents and children.

This paper will focus on the element of the study relating to Bulgarian children aged underthree years. In Bulgaria research relating to this group included interviews and meetings with 4 families; staff from 2 infant homes; staff of 2 small group homes; 2 maternity hospital staff groups including social workers; a range of managers and social workers from 11 child protection departments; 2 foster care teams; director and staff of the State Agency for Child Protection; deputy minister of health; staff of mother and baby unit; 2 judges; staff from a range of NGO projects run by For Our Children; Samaritans and ARK; and UNICEF. Interviews and meetings had the aim of collecting key information using an unstructured format and were recorded through notes. The study received ethical approval from the University of Central Lancashire's ethics committee.

\subsection{Limitations to the study}

The data used in this paper consist of national statistics and those produced by the UNICEF MONEE database, which has collected official data from statistical departments in countries across the CEE/CIS since 1989, as well as studies and reports available through UNICEF and other open sources. It should be noted that statistics provided by different ministries and sources can be contradictory and it is not possible to clearly identify the basis on which they were collected. Similarly, studies are carried out on different bases, are often not based on representative samples, and much information about areas such as the reasons for entry to institutions are collected from official records and there is little formal research in this area. Finally there are large areas where data is not collected. Given the wide range of the original study and the relatively short time-scale most interviews did not focus entirely on issues for infants. This original research has been supplemented by a further review of literature on existing practice.

Also there is a limited evidence base for gatekeeping practices in low and middle income countries (Fluke et al, 2012) consequently this paper is limited to considering "promising practices" (Boothby et al, 2012) which are yet to be fully scientifically evaluated. 


\section{Theory and Background}

\subsection{Regional Context}

The CEE/CIS region is in the process of transition from command economies to market oriented societies. Most of the countries in this transition inherited a system of child protection which focused almost entirely on the use of institutional care for children in difficulty. The focus on institutional care has both economic and ideological causes (Markova, Shilkret \& Djalev, 2008). Traditional extended family networks were disrupted by economic forces of industrialisation and urbanisation. Soviet ideology sought to end the role of the family in perpetuating inequalities and liberate women from domestic responsibilities to encourage their paid employment. This led to the development of an extensive system of state childcare and resulted in a growing belief that state provided care was better than family based care (Sugareva, 1996 cited in Markova et al, 2008).

A decade after the fall of soviet power, in many countries in the region, the number of children living in institutions had increased (UNICEF 2001). By the end of 2010 the UNICEF TransMONEE database showed a fall in numbers, but 724,000 children were still in institutional care across 28 countries of the CEE/CIS and 31,500 children were in infant homes in the 16 countries providing this information (UNICEF, 2012: tables 8.1 and 8.6). However, there are disputes as to the full extent of children in institutional care. Carter (2005: 17) claims, for example, that an accurate estimate of the number of children in institutions in 2002 was considerably higher than the TransMONEE database suggested.

The issues concerning the use of institutional care in CEE/CIS go beyond the numbers involved. The quality of care in institutions is considerably lower than that found in other European countries, there being many large institutions with impersonal care; high proportions of very young children institutionalised (UNICEF 2010b); and very poor conditions for many children with a disability (European Coalition for Community Living, 2010: 17). There is now a wide range of research evidence on the negative impact of these types of institutions on infants (see Bilson 2010, for an overview). Care of children in institutions is medicalised and children remain under-stimulated and receive little warmth or emotional care (e.g. Markova et al., 2008). Problems encountered by institutionalised younger children include lower IQ than those in foster care and compromised brain development (Nelson et al 2007; Van ljzendoorn, Luijk \& Juffer, 2008); reduced growth and weight (Zeanah, Smyke \& Settles, 2006); poorer language acquisition (Windsor, Glaze \& Koga, 2007); and increased levels of mental health problems (Bos et al 2011; Rutter et al, 2007; Sigal, Perry, Rossignol \& Ouimet 2003). These problems are compounded for Roma children who are over-represented in institutions. Whilst there, they face ill-treatment, are often segregated into separate schools and have little support to stand up for themselves against discrimination. On leaving, many lack strong social support networks; many reject their ethnic identity; and they are at increased risk of being trafficked. Some go on to have 
children who will themselves be institutionalised (European Roma Rights Centre (ERRC), 2011).

\subsection{Approaches to Gatekeeping}

The term gatekeeping is used in western social welfare and health literature to refer to a continuum of strategies ranging from 'managed care' aimed at rationing access to scarce services, to processes of professional decision-making based on individual assessments of need and aimed at managing systems (Bilson and Harwin 2003). 'Managed care' definitions of gatekeeping associated with privatisation and reducing costs are more widely used in the health sector. This paper focusses on a systems management definition of gatekeeping and specifically to a strategy for reducing the placement of children in residential care, that is a:

'process of assessment and planning of children's needs and circumstances which should precede their admission into residential care, and contribute to their onward progression-back to their families, into a form of substitute family care, or ... moving to some form of independent living.' (Tolfree 1995: 50)

Rather than an individual decision-making oriented approach gatekeeping mechanisms should also 'oversee, as far as possible, the entire network of policy and procedures' (Thorpe et al,. 1980). Such a systems approach to gatekeeping was suggested in juvenile justice to avoid net-widening, a system effect in which alternatives to prosecution or penal sentences within criminal justice systems attract a less delinquent client group and draw more people into the system (see for example Smith, 2010).

Tolfree (1995) drew on the work of Save the Children in low income countries and some early experience in the CEE/CIS to identify three key characteristics of gatekeeping: preadmission assessment and planning; planning for children already in residential care; and planning for leaving care. Echoing Thorpe et al. (1980), Tolfree expressed concern about the possibility of drift into residential care, noting that 'all too often residential care is seen as "the solution" without an exploration of "the problem"' (1995: 68). He argued that gatekeeping must ensure planning for children in residential care to maintain links with families, for return home where possible or for move on to longer term placement. He highlighted the need for multi-agency working. Bilson and Harwin (2003) developed the concept of gatekeeping from these examples, other early experiences in the region (e.g. Vozniuk, Taseev, Smoliakov \& Yu 1999), and wider literature to propose a systems based approach outlined in the concept paper and toolkit for UNICEF and the World Bank. A summary of the four basic elements of this gatekeeping is given in Box 1 below.

Insert Box 1 here

Since the widespread use of this toolkit there have been a few evaluations of child care system reforms in the region, including in Georgia (O'Brien \& Chanturidze, 2009; Volpi, Tarkhan-Mouravi \& Sumbadze, 2006), Azerbaijan (UAFA 2007) and South East Europe 
(UNICEF 2008). These show that although gatekeeping remains a central approach, there continue to be barriers to its implementation. The consultation by UNICEF in South Eastern Europe, which included Bulgaria, suggested decision-making can be fragmented; one clear entry point was not always established; but, where gatekeeping was working, it was tailoring responses to individual needs (UNICEF 2008). Different aspects of gatekeeping appear to be more difficult in different countries but there tends to consistently be an absence of alternative community based services, or services are not known to families and difficult to access (Bilson, 2010; O'Brien et al, 2009; UAFA, 2007). A recent review of strategies for improving policy for children without parental care concluded that gatekeeping remains a 'key element of a modern child welfare system' (Engle et al., 2011: 212) though there is as yet limited research on outcomes of gatekeeping (Boothby et al, 2012:726).

(UNICEF 2010b). Between 2000 and 2010 thirteen of the eighteen countries providing information to UNICEF had increases in the rate (per 1000 aged under 18) of children in formal care (UNICEF 2012). Four countries had small decreases and only Georgia had a large decrease. Thus as numbers in residential care fell this was mostly accompanied by a larger increase in those in foster care or guardianship. Figures before 2002 were not available for Bulgaria but there is a small increase in rates in formal care between 2002 and 2010 despite reductions in numbers institutionalised. Thus there appears to be a system effect in which formal care increases despite efforts to introduce gatekeeping, and where institutional care is replaced it is mostly with fostering and guardianship rather than support for birth families (UNICEF 2010b:24). Thus the children of socially excluded and poor families who previously went into institutions (Tobis 2000) are still losing parental care.

\subsection{A Social Development Orientation}

It is because of the above problems that this paper proposes the need for an orientation that places gatekeeping's focus on assessment and service provision within a frame that promotes support for birth families and includes responses to the specific elements of poverty and social exclusion that lead to the breakdown in families. In Bulgaria, a member of the European Union, almost half (44.6\%) of all children are at risk of poverty or social exclusion (Eurostat 2012). Whilst Bradshaw and Holmes' survey (2010) found poverty affected $57 \%$ of all children this increased to $92 \%$ of Roma children. An estimated $60 \%$ of Roma were unemployed in 2006 (World Bank, 2010). Access to health services are severely limited (Rechel, Blackburn, Spencer \& Rechel, 2009); housing is poor and conditions deteriorating (UNDP, 2005); and policies targeting the inclusion of school aged children have started too late and did not address infants (Gabel, 2009). Even having controlled for family size, unemployment and other risk factors, the odds of a Roma child living in poverty are around three times higher than a non-Roma Bulgarian child (Bradshaw \& Holmes, 2010). Responding effectively to socially excluded groups is not only a problem for middle income countries like Bulgaria. The situation of Roma parallels that of socially excluded minorities 
such as aborigines, Native Americans or First Nation People in Australia, Canada and USA. Here there have been recent apologies for the use of residential care that was used to 'assimilate' these groups (Corntassel \& Holder, 2008; White Bison, 2010; Marr, undated). Despite this, current trends show child protection in these countries has led to an extremely high level of surveillance (e.g. Delfabbro, Hirte, Rogers \& Wilson, 2010) and removal of children from families and communities, in some cases at a higher level than before the apology (Sinha et al. 2011; Overington, 2008).

Given the level of poverty and social exclusion in Bulgaria this paper suggests that, in this early stage of implementing social work, promoting a social development orientation might enhance the current gatekeeping policy in Bulgaria and develop a family support approach rather than one focussed on risk or a forensic orientation (Lonne et al. 2009). At the same time it will be important to maintain the key elements of gatekeeping with its focus on assessment and provision of services according to families' needs.

Whilst there is no agreed definition, . Midgley (2010: 13) describes a social development approach to social work which has a key focus on "tangible improvements in standards of living, health and education, and a concomitant reduction in poverty, malnutrition, and illiteracy." Key features of such an orientation relevant for gatekeeping are:

- Strengths-basis acknowledging and focussing on family and community assets and aiming to promote resilience

- Social investments that enhance capabilities including: "employment placement, childcare, adult literacy, micro-enterprise, and asset savings accounts, to name but a few" (Midgley and Conley, 2010: xii-xiv)

- Interdisciplinary focus including promoting access to housing, medical care, education, and recreational facilities

- Community focussed working with communities to combat social exclusion

- Advocacy based rather than a narrow preoccupation with practice with families and children 
It is recognised that these features are not only the concern of a social development orientation but they are given considerable emphasis in it. This paper will consider the developments in recent work on alternatives in Bulgaria and some examples from farther afield to show that elements of this approach are being found to be effective by those providing alternatives to institutions.

\section{Findings}

This section reviews pathways into and out of infant institutions in Bulgaria and uses the four basic elements of gatekeeping as a frame to assess the strength of the gatekeeping system. Emerging social development orientations in recent work on deinstitutionalisation in Bulgaria are then reviewed, before discussing the implications of the current situation for a gatekeeping approach in Bulgaria and internationally.

\subsection{Pathways in to and out of infant institutions}

According to the TransMONEE figures there has been a fall of $34.0 \%$ in the number of children in infant homes in Bulgaria from 3,375 to 2,350 between 2000 and 2010. The rate per 100,000 children aged 0 to 3 years of children in infant institutions has fallen further, by 42.4\% from 1280.8 to 783.5 per 100,000 children aged 0 to 3 (see figure 1 ). However despite this fall, Bulgaria continues to have the highest rate of children in infant institutions in the region the next highest being Latvia at 414.6 (UNICEF 2012: table 8.6).

Figure 1 Number and Rate per 100,000 population aged 0 to 3 of children in infant institutions $31^{\text {st }}$ Dec 1998 to 2010 


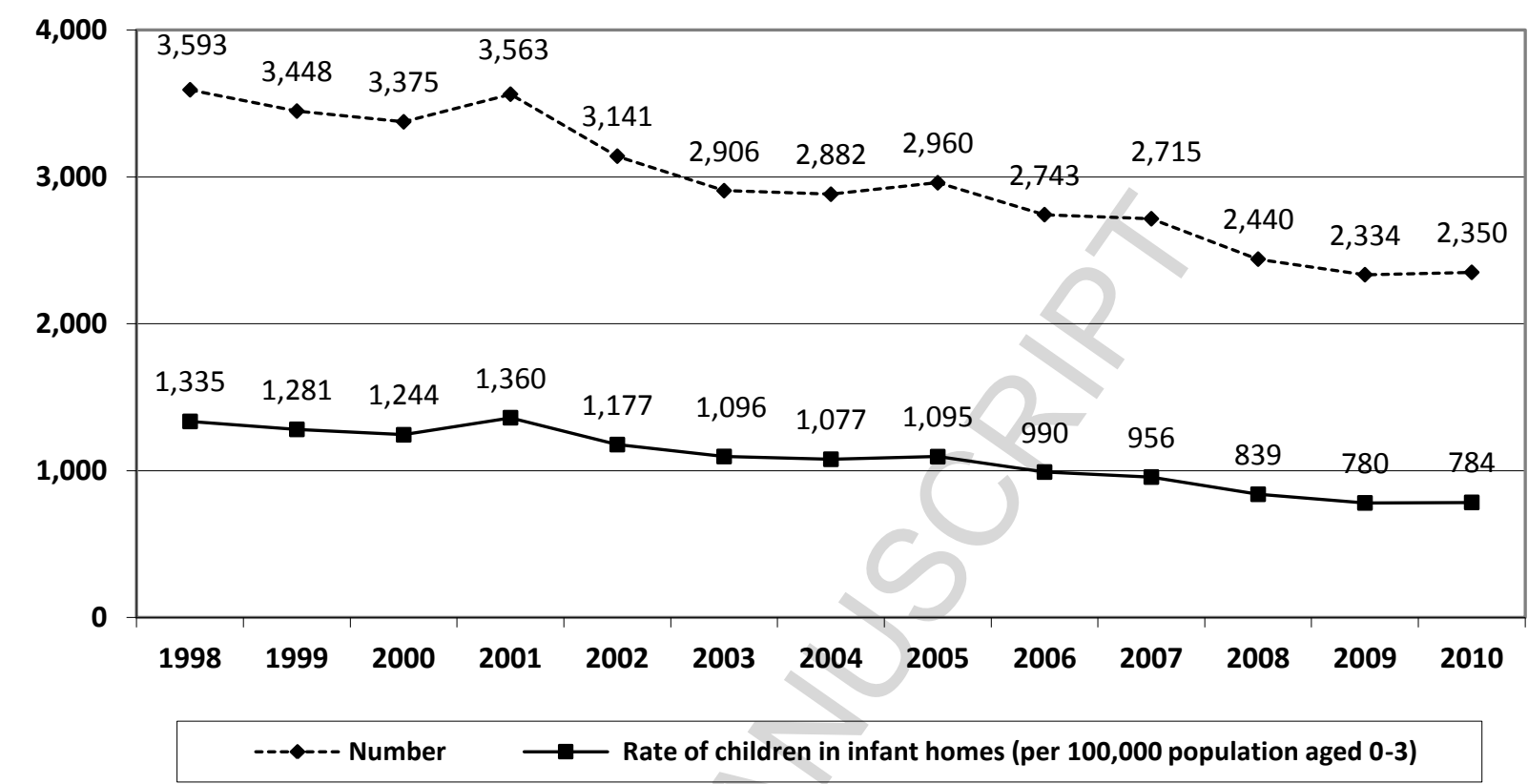

Source: UNICEF 2012a: tables 8.6 and 8.7

These figures for the number of children placed on a particular day underestimate the total number of children who will be placed in an institution throughout a year, thus in the first six months of 2011 there were 961 new entrants to infant institutions. Earlier more comprehensive and comparable statistics show a fall in direct admissions from maternity hospitals from 1,326 babies in 2005 to 966 in 2008. This meant that one in every 78 live babies born in 2008 was admitted directly from the maternity ward to the infant institution. Entry from hospital is partly due to infant institutions providing medical and intensive care facilities; 596 (62\%) of these direct admissions required medical care. However just over a quarter of these babies did not return to their mothers and remained in the infant institution; making a total of 528 children 'abandoned' from maternity hospitals in 2008. The fall in total numbers in the institutions was only 189 between 2005 and 2008, despite fewer babies entering directly from hospital, indicating either an increase in entry through other routes and/or some children remaining longer in the institutions.

There are no national statistics giving reasons for entry to care but there are smaller scale studies showing the demographic composition of different institutions. UNICEF (2007) undertook studies of 129 children resident in two infant institutions, again looking at children in care on a particular date, thus underestimating children on short term placements and over-representing disabled and Roma children who stay longer. They found that the main route into the infant homes was through maternity wards which accounted for $57 \%$ of all residents. A further $21 \%$ entered before the age of 6 months making the first months of life the most vulnerable for entry to institutional care. $21 \%$ of the children had a mental or physical disability which, considering only these children can stay beyond the age of three, means they would represent a smaller proportion of new entrants. 
A national survey of children in infant institutions carried out by the State Agency for Child Protection in 2006, showed that over $50 \%$ were Roma, and for $15 \%$ the ethnicity was unknown (Petrova-Dimitrova, 2009: 13). Other smaller scale studies of institutions show higher figures of 54\% (Ward 2006) and at least 60\% (UNICEF 2007). The 2001 census showed that $4.6 \%$ of the population declared themselves as Roma. Whilst it is felt that census figures may underestimate the number of Roma the upper estimate is that they form $10 \%$ of the population. Thus it is clear the Roma minority in the country is significantly overrepresented in infant institutions.

The UNICEF (2007) study, showed reasons for entry of the children resident in the institutions in July 2007 obtained from files and interviews with institutional staff. Only $8 \%$ entered because of neglect or abuse and $3 \%$ because of parental health problems. The main reasons for entry were for the child to be adopted (29\%), because of poverty (28\%), child health problems $(14 \%)$ or abandonment $(12 \%)$. This latter reason probably hides further problems of poverty. There was only a low level of instances where the reason given was single motherhood (4\%), a significant point given the emphasis on this as a key reason for 'abandonment' mentioned by stakeholders (Bilson and Markova, 2007).

The fieldwork for this study, and earlier research in Bulgaria interviewing 12 further families also undertaken by the first author of this paper (Bilson and Markova, 2007), give some indications of the pressures that lead to infants being placed. Parents of disabled children said they were advised by medical staff in hospitals to give up their children and this was confirmed by various medical and social work staff. These parents also complained that they were given no offers of support for children when making the decision whether to keep their child. For example parents of one child were told that their child had a serious and untreatable condition and that the child would be better off in an institution. The parents later discovered that the child had eczema ${ }^{1}$. Poverty was cited as a key reason why children entered institutional care. This includes a range of issues related to housing, low income and access to benefits. These findings confirm existing research which shows frequently Roma families have poor accommodation without basic facilities such as water supply, electricity or toilets and only a single small room for a large family (Ward, 2006).

National figures for the placement of the 1,796 children leaving infant institutions during 2008 are shown in table 1 . About a quarter of the total children leaving were those who went home following entry for medical treatment. A further $19.5 \%$ returned home. The most common placement was adoption whilst placement in foster care (2.2\%) and kinship care $(1.2 \%)$ was relatively rare. More recent figures for the first half of 2011 show an increase in foster care to $6.9 \%$ of those leaving and that $3.1 \%$ of the children died. These figures are not used further due to a large proportion (31.3\%) of data classified only as 'other.'

\footnotetext{
${ }^{1}$ Personal communication from team involved in closure of Teteven Infant home.
} 
Table 1 Placement of children leaving the infant homes in 2008

\begin{tabular}{|l|l|l|}
\hline Placement on leaving & Number & Percentage \\
\hline Transfer to specialist institution & 357 & $19.9 \%$ \\
\hline Adoption & 592 & $33.0 \%$ \\
\hline Foster family & 39 & $2.2 \%$ \\
\hline Kinship care & 21 & $1.2 \%$ \\
\hline $\begin{array}{l}\text { Reintegration to families - babies entering for } \\
\text { medical treatment }\end{array}$ & 438 & $24.4 \%$ \\
\hline Reintegration to families - other children & 351 & $19.5 \%$ \\
\hline Total & 1796 & \\
\hline
\end{tabular}

Nearly one in five (19.9\%) left to be placed in institutions past the age of 3. Many of these were specialist institutions for disabled children.

Although adoption remains proportionately the most frequent exit route from institutions in Bulgaria, the number of children being adopted has fallen by $55.6 \%$ from 2140 in 2000 to only 950 in 2010 (UNICEF 2012). Both international adoption (falling by $75.6 \%$ from 1005 to 246) and national adoption (falling by $38.0 \%$ from 1135 to 704 ) have dramatically decreased in this period though numbers have increased since the low of 674 adoptions in 2008. The fall in international adoption coincided with the implementation of Bulgaria's ratification of the Hague Convention as well as the negotiations to enter the European Union. Whilst this drop in adoptions is substantial it should be noted that in 2010 Bulgaria had the highest rate of adoptions of the 22 states providing this data to the TransMONEE database (UNICEF 2012: tables 8-12).

\subsection{Decision-making based on assessment and review of children's needs}

\section{and family circumstances}

The legislative framework for child protection is one of the most advanced of the countries that inherited a soviet child care system. The Child Protection Act (CPA), passed in May 2000 and amended several times, is key. The CPA Regulation on decision making by Child Protection Department (CPD) social workers, state that a child in need of special protection shall be referred to a social worker who must carry out an initial assessment within 10 days. A case assessment must be completed within 4 weeks along with an action plan of short and long term goals, agreed with the parents. The regulations also describe the duty to consider placement with the wider family where a child's parents are considered unfit or unable to provide care.

In order to ensure children are referred for assessment from maternity hospitals an ordinance requires them to nominate a member of staff to identify children at risk of abandonment and to refer them to the CPD. Except in the case of an emergency, any child placed in an institution should have been assessed by the social workers at the CPD and an 
order made by a court. In an emergency when "the child's health and life are at risk," the Director of the Social Assistance Department can make an order to place a child in an institution or foster care, but this must be taken to court within a month.

The CPA also legislates for planning for children placed in the infant institutions and plans should be reviewed every three months, with involvement of the parents, child and other interested parties. A weakness of the CPA is that, in order for a child to return home, the court order must be rescinded and this requires a parent to apply to the court with no access to legal aid.

Whilst there is a strong legislative and procedural framework, interview respondents noted a range of problems in practice (see also Ward 2006). In many cases referrals take place only after the mother has decided to abandon her child (UNICEF, 2007). As section 4.1 above showed, at least a third of children from the maternity hospital who eventually stay in the institution entered for medical treatment and thus are likely to have avoided assessment prior to entry. There is a later assessment but often parents are no longer traceable and the bond with the child has not been established. The by-passing of a court order, through an administrative order which should only occur in emergencies, has become the most common entry route (Harizanova, 2007: 27). Once in court respondents said parents were often not represented and, according to judges, there was little challenge to the recommendation of the social workers and almost no orders were rescinded. This means that the court system is currently not effective in challenging social workers and defending parental or children's rights.

The planning process was also limited. It was reported in interviews that the reviews and planning meetings were either not done or carried out in a peremptory fashion. Previous research shows plans, where they exist, are often hopeful rather than realistic (Ward, 2006) and where the CPD plan was for a return to parents, little work may be done to help parents to maintain contact with their child or to prepare the family for the child's return (UNICEF, 2007). Ward's (2006: 6) study found that $78 \%$ of children had little or no contact and only $11 \%$ had weekly contact.

The fieldwork for the current study showed institutions were forbidding places for parents to visit and visiting facilities were poor. On one visit to an institution the visiting parents were sitting in a corridor with their child whilst a member of staff sat coldly observing them. Parents are actively discouraged from contact and visiting times are limited. Parents can be required to get medical certificates before they are allowed to visit their child. Markova et al. (2008) describe a group of parents complaining they only had access to their children for 10 minutes through the institution's backyard fence. In addition the current study revealed little effective planning for the on-going care of children. For example there continue to be practices that prevent the opportunity to form attachments to care staff, such as having children move frequently between staff groups catering for different age ranges. Such 
practices increase the likelihood of children having developmental delays, limited speech and reduce the possibility of successful reintegration or adoption.

\subsection{A range of services in the community providing support to children}

\section{and their families}

The CPA Article 4 describes the responsibility to provide a range of support. This responsibility is devolved to the municipalities supported by the 148 CPDs that operate at that level. There is consequently a degree of decentralisation that could enable planning to occur closer to local communities (Bosnjac and Stubbs, 2007). Although World Bank funding helped to establish services in 10 pilot areas, the range of community based services available across most of the country is very limited and in many cases key services are unavailable. There were family centres in these 10 areas but beyond this, community resources to support social work were limited except in a few municipalities where international NGOs provide them.

In many municipalities the only locally based services to support families was the advice and support of social workers in the CPD and the possibility of some limited financial payments. Whilst this was sufficient for some families, in many cases this appeared to lead to social workers trying to persuade parents or carers to carry on caring rather than assessing the situation and developing a plan for support. For example, ARK (2007: 5) reported a grandmother whose schizophrenic daughter had outbursts in which her child, who had special needs, was considered to be at risk. The grandmother was persuaded to keep the child but the family could not afford medication needed to control the mother's mental health problem. Medication and mental health support were not supplied. There was little help given for the child's special needs. When the grandmother could no longer cope the child eventually entered an institution.

The current study found similarly little support for disabled children and their families. Though some infant homes offer day care for disabled children this is a limited resource often unavailable because of distance and lack of transport, particularly for Roma families who live in isolated communities. A study of one such institution found that none of the 114 children using daily care were Roma whilst 65 of the 80 children placed residentially were Roma (UNICEF 2009). One interviewee involved in undertaking this study said this was largely due to segregation and prejudice.

Further, there was a lack of even basic preventive services. For example, parents, social workers and NGO reports mentioned housing as a key problem leading to placement of children in infant institutions, with many children being from large mainly Roma families who share a single room, often with other family members. It was reported that mothers can be placed under pressure by family, or made homeless, if they do not abandon their 
child. Despite this there was little done to support families through providing access to housing.

Foster care has been very slow to develop (only 198 children were placed in foster care during 2008) and effectively took the form of paid adoption with little provision apart from long term care. There was almost no short-term foster care as an alternative, for example, to the placement of babies in institutions whilst they wait to be adopted. There is currently a government project working to increase availability of foster care but there is a long way to go. There are some residential mother and baby homes for single parents ( 9 units with 71 places) but these are underused, probably because relatively few first-born children enter institutions and, although not married, most 'single mothers' are in a relationship with the father of the child (Bilson and Markova, 2007; UNICEF, 2007).

The major development in care placements for children has been in the use of kinship care with 5,173 children placed on 30/06/2008 (Petrova-Dimitrova, 2009), though this is used as an alternative placement more than a route out of institutions. This is often carried out by grandparents and increasingly whilst parents travel to work overseas (Delap 2012: 9). Kinship carers currently receive little support and are often female, older and impoverished (Delap 2012: 18). The social work intervention mainly consists of identifying and persuading someone to care. Kin carers require a range of support including psychosocial support but also help with: Healthcare - both for themselves and their families; Discipline - especially of adolescents; Material needs - especially providing food for the family; School fees and uniforms; Accessing social protection, such as pension and foster care grants; and Getting the right documentation for children, such as birth certificates (HelpAge International and REPSSI, 2011).

There are a range of social welfare benefits for families in Bulgaria and the child social protection package is one of the highest in the region, but by far the majority of child benefit is means tested (Bradshaw, 2012). Roma parents often do not have the documentation needed to collect benefits or are not registered as unemployed and are thus denied social benefits and Roma women, most of whom do not have formal employment histories, are not eligible for benefits based on work related social payments (Gabel, 2009).

\subsection{An agency responsible for coordinating assessment of a child's}

\section{situation}

In 2007 there were 811 social workers in CPDs. They have the key role of carrying out assessments of children at risk; designing plans for the children; reviewing plans including the plans for children in institutions as well as coordinating the services provided to children at risk. Municipalities vary in size and some are so small they employ only a single worker who also has to perform other roles alongside social work, consequently there is a lack of specialist knowledge. Social workers have other responsibilities outside entry to care and 
children in institutions and this means that their workloads are very high. At the same time, and as noted in other research (Davis, 2006; Browne, Chou \& Whitfield, 2012), social work staff are paid on very low salaries close to the minimum wage. Unsurprisingly there is a high turnover, especially of experienced staff. This leaves a workforce where few are qualified social workers. The level of education is often below that of a professional in other spheres and there is a lack of adequate social work training. There is also a lack of managers with social work experience and the equipment needed to work with families such as transport and mobile phones is mostly inadequate or missing. Whilst basic training has been supplied there is no standard for social worker's education and no licencing.

To return to some of the founding theory of gatekeeping, Tolfree (1995) noted that the philosophy underpinning gatekeeping may be more important than resources and Bilson and Harwin (2003: 8) also stated:

Reforms are unlikely to be effective without a shift from the paradigms of rescue, state paternalism, ethnic discrimination, and the deficit model of disability.

Although there is much variability between CPDs in their attitudes to the use of institutions (ARK 2007), the findings from this study suggest that a paradigm shift has not occurred in all quarters. There is discrimination against Roma and disabled children. Staff preconceptions, about difficulties of parenting certain children or uncertainties about parental capacities of some adults, lead to encouragement of infant abandonment. Other research (ERRC, 2011) suggests CPDs may target the removal of infants born to Roma single mothers or girls aged under 16; and preventive measures to address structural patterns of social and economic disadvantage were not adequate.

\subsection{Information systems providing feedback on the operation of the}

\section{system and able to monitor and review decisions and their outcomes.}

Information is needed to steer effective gatekeeping strategies, to plan new services and to target limited resources. This means there is a need for research and data on flows through the care system. There were a small number of limited studies in this area (ARK, 2007; 
Bilson and Markova 2007; UNICEF 2007, 2009) though none were comprehensive. There was also some basic information gathered on an annual basis by the State Agency for Child Protection. However this was limited to a snapshot of children in care giving numbers and ages of children in the homes at the end of the year and some data on numbers of entrants and exits during the year. For example there was no information on the numbers of children who had entered care from different localities, nor on the reasons children entered care. In Bulgaria the Protection of Personal Data Act and EU legislation is "wilfully misinterpret[ed]" (ERRC, 2011: 67) as prohibiting the collection of data on racial or ethnic origin. However the concluding remarks on Bulgaria's report to the Committee on the Rights of the Child (CRC) asks for data to on all aspects of children's rights to be disaggregated "according to sex, age, urban/rural areas and ethnic or social origin" specifically mentioning the need for information on the Roma minority to be available (CRC 2008: 4).

\subsection{Recent developments and social development orientations}

Following the Council of Ministers adoption of the National Strategy "Vision for deinstitutionalization of children in Bulgaria" and the Action Plan to execute it in 2010, there have been a number of further developments relevant to under three year olds. A national project has been implemented to recruit foster parents and further programs are under way to increase the number of social workers. The first closure of an infant institution was carried out by a local municipality and two NGOs (Equilibrium, 2012). A further institution is being closed with the support of UNICEF. Despite the fall of about a third in numbers of children in the infant institutions mentioned earlier, there had not been a single closure of one of the 32 institutions until these projects. Hope and Homes for Children are using the model they used in closing the home in Teteven to guide the closure of seven further infant institutions. Thus plans for improvement are being implemented by government in many of the problem areas.

There is evidence in Bulgaria and elsewhere in the region that practices incorporating the key elements of a social development orientation are being implemented in gatekeeping strategies. This is explored in the subsections below.

\subsubsection{Strengths-basis}

A strengths-based approach to work with children, families and communities promotes empowerment and challenges the medicalised and paternalistic models that are the inheritance of the Soviet era (Saleebey 1996). Practices which demonstrate the potential of such an orientation in the first element of gatekeeping (assessment of families' and children's needs) include the ACTIVE model used in the closure of Teteven. This strengthsbased programme focuses on six areas of well-being: Living conditions; Family and social relationships; Behaviour; Physical and mental health; Education; and Employment and household economy (Sofovic et al, 2012: 15). It uses a strengths-based assessment of the family. It has proven effective, according to a programme evaluation, in preventing 
institutionalisation of children in Bosnia and Herzegovina (Sofovic et al, 2012) and in Teteven, Bulgaria (Equilibrium 2012; Bilson and Markova, 2012). CPD staff most involved in the work in Teteven were empowered by this strengths orientation saying that for the first time they saw parents treated with dignity and this led to them no longer being concerned "about our own security, about a fear what to do with abandoned children" but rather "what are the alternatives for these children" (Bilson and Markova, 2012).

Similarly Family Group Conferencing is also used in Bulgaria (Tulip Foundation 2012) and was found to be a promising practice by the Evidence Summit on Protecting Children Outside of Family Care (Fluke et al. 2012: 725).

\subsubsection{Interdisciplinary focus}

The problems that lead to institutionalisation cross boundaries and include health, education, housing and much more. In Bosnia ACTIVE developed partnerships with "a number of local schools, health services, employment agencies and NGO's. These organisations refer individual children and families to the programme and also offer support within the programme in their respective areas of expertise" (Sufovic, Kragulj, Pop, 2012: 10). It has been found helpful in a number of countries to establish multi-agency decision making panels, that may include professional specialists and members of parliament, trained on child rights, foster care and related issues, with the purpose of making decisions about access to support for families and fostering (e.g. Georgia see Reichenberg and Nordenmark, 2006; Moldova see Carter 2006a; Ukraine see Carter 2006b). This again seems to reinforce the effectiveness of decision making, the first element of gatekeeping.

\subsubsection{Social investments}

The ACTIVE approach discussed above offers specific practical support, for example providing help to get adequate and secure housing, house repairs and assistance in obtaining employment. In use in Teteven it was found that practical support including 'food and baby supplies, finance for the issuing of documents, travel expenses, building materials and firewood' (Equilibrium 2012: 9) was often the major need of families and this reflects similar findings from a study conducted by Roma researchers into the needs of parents of children who had recently entered institutional care (Bilson and Markova, 2007).

Social investment initiatives have been successful in Bulgaria (e.g. Rowe et al., 2009) and elsewhere within the region and these could be focussed on communities with high rates of children in state care. For example, microloans have been used in Romania (Davis 2006) where in local communities and particularly for women; this has helped people provide their basic needs, such as running water, extra rooms for children, and local economic development. In Slovakia a micro savings project was found to be helpful in reducing poverty for Roma families (Zelinsky, 2009). 
Social protection, which combines social support and financial assistance, has been adopted by a number of countries within CEE/CIS (Bilson and Westwood, 2012). It has shown some success where effectively targeted and accompanied by a multi-disciplinary approach to poverty reduction, focused on increasing access to housing, health, education and employment (Gabel, 2009; Kukova 2011). In Ukraine, for example, a substantial increase in both the maternity grant and the monthly social assistance payments following birth and increased payments for those with more than one child have contributed to reducing abandonment (Bilson, 2010).

\subsubsection{Community Focus}

Community-based approaches that promote social integration were identified as a promising practice by the Evidence Summit (Boothby et al. 2012). There are a few examples of planning and running services with active participation of the affected communities Roma communities, as Amalipe, a Roma NGO based in Bulgaria, demonstrate. They are working through community development centres, focused only indirectly on abandonment, using questionnaires to identify local people's views on risks and services that may be needed (Lazarov and Kolev, 2012). Similarly Roma women were involved in research into the needs of women whose children were placed in an infant home in Rousse (Bilson and Markova, 2007). Systematic planning based on the views of families and communities has been shown to lead to the provision of new services that better meet existing local needs (see for example ARK, 2009). Similarly the involvement of Roma communities in evaluations of projects, though relatively rare, has provided vital information about levels of satisfaction with current conditions and perceptions of future programs (De Sas Kropiwnicki and Deans, 2006).

The second element of gatekeeping is then, in some instances, being strengthened by provision of a range of practical, social investment and social protection services and interventions in communities. This has proved particularly effective where service developments involve and support communities.

\subsubsection{Advocacy}

There have been some high profile advocacy campaigns on institutionalisation, in different forms. The challenging BBC documentary, The Abandoned Children of Bulgaria, broadcast in the UK and Bulgaria in 2007, led to a public reaction against institutions in Bulgaria. More persuasive forms of advocacy have also been effective, such as a UNICEF TV campaign in which six pairs of celebrities performed a song and discussed "the process of deinstitutionalization and the effects of institutionalization on children's development" (UNICEF 2011: 7). This not only raised public awareness and funds for UNICEF but also influenced government policy, being one factor behind the government's change of policy and commitment to deinstitutionalisation (UNICEF 2011). 
Other examples of advocacy include the collective complaint lodged by the Mental Disability Advocacy Centre and the Bulgarian Helsinki Committee (BHC) which led to a decision of the European Committee of Social Rights (ECSR) in November 2008 that Bulgaria was in violation of the European Social Charter because of "discrimination against children with moderate, severe or profound intellectual disabilities residing in [Homes for Children with a Disability] as a result of the low number of such children receiving any type of education when compared to other children" (ECSR, 2008: 15). The BHC has also campaigned on a number of other issues including their investigation with the Prosecutor's Office of 238 deaths in disabled children's institutions between 2000 and 2010 which were not subject of a post-mortem (the full reports are in Bulgarian for a summary see http://forsakenchildren.bghelsinki.org/en/). Such advocacy strategies challenge unethical practice and aim to progress the paradigm shifts that need to occur in order for gatekeeping to thrive.

\section{Discussion}

Overall these findings show that there has been much progress in developing gatekeeping in Bulgaria for infants. In particular there has been a fall in children in institutional care and there is a comprehensive legal system and procedures for assessment and decision-making in place and a national social work service is being developed. Furthermore there is a commitment from government, with the support of the European Union, to close all large institutions. There are also some examples of good practice on which to build. The study described above identifies a number of issues including: limited numbers of staff in child protection departments; poor practice, variable commitment to deinstitutionalisation and lack of training of social workers; a shortage of foster care; limited support for kinship care; very limited data on the operation of the social work system; limited community alternatives to support families; and problems with court decision making. Many of these are being considered in government plans.

Despite this positive starting point there remain many problems, not least of which is the overall increase in children without parental care mentioned earlier. Also, in the case of older children with a disability, the plans for deinstitutionalisation are further progressed and effectively involve the building of small group homes with the same capacity as the institutions. Whilst such a move is doubtless for the better, it demonstrates a tendency for the positive approach of the government to lead to continuations of children living without parental care rather than providing family support. To combat this social work practice requires much further development and an orientation that will allow it to challenge the underpinning problems of social exclusion and focus on supporting families. 


\subsection{Incorporating a social development orientation into gatekeeping}

Many of the elements of social development are being implemented in small scale projects and programmes and examples have been given above. For a social development orientation to be incorporated into gatekeeping would require many of these practices demonstrated in programmes like the ACTIVE programme used in Teteven, to become mainstream. As found in Teteven, this approach helped CPD staff to reconsider their approach to families showing, at this local level, that a paradigm change is possible. However a number of key areas would require to be addressed:

- A strengths-based curriculum for training in social work and social work practice would need to be adopted and supported at a national level in policy and in social work agencies

- Assessments would: a) focus on family and community strengths and assets rather than on deficits; b) consider the impact of wider systems including how structural stressors including poverty, housing, medical care and education can be diminished; and c) involve participation of families and communities

- A range of services should be extended beyond social work support and alternative family based care to include prevention through approaches such as: social investments and social protection; community strengthening and local advocacy; and support for kinship care

- Include an advocacy element focussed on issues central to promoting family support and combating institutionalisation

A strategy to introduce gatekeeping has limitations and cannot be expected to singlehandedly combat social exclusion and poverty. It will thus need to target key elements of the system. One requirement for this would be an effective information system for care and social work services, disaggregated to be locally sensitive. This could then be used for targeted interventions and resources. For example it could assess whether certain hospitals had higher rates of children relinquished by parents and then carry out studies to find why this is the case using this information to develop targeted responses in areas such as 
changing staff practices, health care in the community, social work support for families and so on.

Finally the proposals made in this paper are based on the study in Bulgaria and the authors' wide involvement in developing gatekeeping internationally. Studies of the impact of gatekeeping (Fluke et al. 2012) and strengthening child protection at a national level in middle and low income countries (Bilson and Westwood, 2012) are sadly lacking. Further research in this important area is required.

\section{Conclusion}

Much has been achieved in Bulgaria in developing gatekeeping though levels of infant institutionalisation remain high. This paper proposes a social development orientation in gatekeeping and shows that many of the elements of this are being implemented in projects run by NGOs. Many governments in the CEE/CIS are attempting to implement gatekeeping policies, but combatting ingrained responses to socially excluded and poor families is proving difficult. Gatekeeping requires an orientation that helps those involved focus on promoting family support and addressing underpinning issues of social exclusion and poverty. This paper outlines key elements of a social development orientation, giving examples of how it might be incorporated into gatekeeping strategies. Changing patterns of institutionalisation in a country requires not only concrete actions in developing legislation and services but also a change in the way the state and others respond to the problems faced by families. There is as yet no formal evidence on the best approach to gatekeeping but it is hoped that this detailed look at the patterns of institutionalisation of infants in Bulgaria and the recent developments in supporting families contributes to the growing knowledge in this important area.

\section{References}

ARK (2007). Preventing institutionalisation - Bulgaria: Topic guide with summary analysis of community interviews and observations. Stara Zagora, ARK

ARK (2009). Bulgaria prevention work briefing. Stara Zagora, ARK

Bilson A. (2009) "Use of Residential Care in Europe for Children Aged Under Three: Some Lessons from Neurobiology" British Journal of Social Work 39(7) pp.1381-1392

Bilson A. (2010) The Development of Gate-Keeping functions in Central and Eastern Europe and the CIS: Lessons from Bulgaria, Kazakhstan and Ukraine. UNICEF, Geneva http://www.unicef.org/ceecis/overview_Report_20_August_preface.doc

Accessed 13/06/2013 
Bilson, A., \& Harwin, J. (2003). Changing minds, policies, and lives: Gatekeeping services for vulnerable children and families. Florence: UNICEF Innocenti Research Centre and World Bank Group.

Bilson A. and Markova G. (2007) "But you should see their families: Preventing child abandonment and promoting social inclusion in countries in transition" Social Work and Social Science Review 12(3): 57-78

Bilson A. and Markova G. (2012) Appreciative Inquiry evaluation of the closure of Teteven DMSGD. Unpublished report for Know How Centre on Alternatives to Care for Children, Sofia

Bilson A. and Westwood J.L. (2012) Making Social Work Work: Improving social work for vulnerable families and children without parental care around the world: A literature review. London, EveryChild. http://www.everychild.org.uk/docs/MakingSocialWorkWork.pdf Accessed 13/06/2013

Boothby, N., Wessells, M., Williamson, J., Huebner, G., Canter, K., Rolland, E., \& ... Walker, V. (2012). What Are the Most Effective Early Response Strategies and Interventions to Assess and Address the Immediate Needs of Children outside of Family Care? Child Abuse \& Neglect: The International Journal, 36(10), 711-721.

Bos, K., Zeanah, C.H., Fox, N.A., Drury, S.S., McLaughlin, K.A., Nelson, C.A. (2011). Psychiatric outcomes in young children with a history of institutionalization. Harvard Review of Psychiatry, 19, 1, 15-24.

Bošnjak V. and Stubbs P. (2007). Towards a New Welfare Mix for the Most Vulnerable: Reforming Social Services in Bosnia-Herzegovina, Croatia and Serbia. Social Policy and Regional Development Proceedings Zagreb, The Institute of Economics and Friedrich Ebert Stiftung

http://citeseerx.ist.psu.edu/viewdoc/download?doi=10.1.1.113.6536\&rep=rep1\&type=pdf accessed on $11 / 12 / 12$

Bradshaw, J. (2012). The case for family benefits. Children and Youth Services Review 34, 3, 590-596.

Bradshaw J. and Holmes J. (2010). Child Poverty in Bulgaria: A Report for UNICEF. York, SPRU http://www.york.ac.uk/inst/spru/research/extreme/CP2.pdf accessed on 11/12/12

Browne, K. Chou, S. and Whitfield, K. (2012). Child Abandonment and its Prevention in Europe. Nottingham, University of Nottingham.Carter R. (2005). Family matters: a study of institutional childcare in Central and Eastern Europe and the former Soviet Union [Full version]. London, EveryChild.

Carter, R. (2005). Family Matters: A study of institutional childcare in Central and Eastern Europe and the Former Soviet Union. London: Everychild. 
Carter R. (2006a). Evaluation of the TACIS project "Capacity Building in Social Policy Reform in Moldova". Chişinau, EveryChild Moldova.

Carter R. (2006b). Report for UNICEF on the Reform of Child Welfare in Ukraine (UNICEF Contract No: SSNUKRA/2006/00000469-0). 6 December 2006.

CRC (2008). Concluding Observations: Bulgaria CRC/C/BGR/CO/2, 23 June 2008. Geneva, CRC.

Corntassel J. and Holder C. (2008). Who's Sorry Now? Government Apologies, Truth Commissions and Indigenous Self-Determination in Australia, Canada, Guatemala and Peru. Human Rights Review 9(4): 465-489

Davis, R. (2006). Emerging Practices in Community-Based Services for Vulnerable Groups: A Study of Social Services Delivery Systems in Europe and Eurasia. United States Agency for International Development: Washington DC, USA, [online] Available at: http://transition.usaid.gov/locations/europe_eurasia/dem_gov/docs/comparative_country_stud y_final.pdf accessed 11/12/2012

De Sas Kropiwnicki, Z. and Deans, F. (2006). Mapping the Terrain: Exploring Participatory Monitoring and Evaluation of Roma Programming in an Enlarged European Union. Oxford, INTRAC.

Delap E. (2012). Family first: Prioritising support to kinship carers, especially older carers. EveryChild and HelpAge International, London.

Delfabbro, P.H., Hirte, C., Rogers, N., \& Wilson, R. (2010) "The over-representation of young indigenous people in the South Australian child system: A longitudinal analysis" Children and Youth Services Review, 32, 1418-1425.Engle, P. L., Groza, V. K., Groark, C. J., Greenberg, A., Bunkers, K. M. and Muhamedrahimov, R. J. (2011), VIII. The situation for children without parental care and strategies for policy change. Monographs of the Society for Research in Child Development, 76: 190-222

Equilibrium (2012). Transforming Lives: the Teteven Deinstitutionalisation Project. Available on line http://eq-bg.com/userfiles/transforming_lives.pdf accessed 11/12/12

ERRC (2011). Life Sentence: Romani Children in Institutional Care. Budapest, The European Roma Rights Centre.

European Coalition for Community Living (2010). Wasted Time, Wasted Money, Wasted Lives ... A Wasted Opportunity? European Coalition for Community Living http://www.community-living.info/documents/ECCL-StructuralFundsReport-final-WEB.pdf accessed on $10 / 12 / 12$

ECSR (2008). Decision on the merits: 3 June 2008: Mental Disability Advocacy Center (MDAC) v. Bulgaria: Complaint No. 41/2007. Strasbourg, Council of Europe downloaded on 
$30 / 11 / 2012$

from

http://www.coe.int/t/dghl/monitoring/socialcharter/complaints/CC41Merits_en.pdf

Eurostat (2012).Statistics in focus - 9/2012

EveryChild (2007). Written Contribution for Committee on the Rights of the Child Day of General Discussion. EveryChild, London http://www.crin.org/docs/UN\%20Discussion\%20Day\%202007\%20submission\%20from\%20 EveryChild\%5B1\%5D.pdf

Fluke, J. D., Goldman, P. S., Shriberg, J., Hillis, S. D., Yun, K., Allison, S., \& Light, E. (2012). Systems, Strategies, and Interventions for Sustainable Long-Term Care and Protection of Children with a History of Living outside of Family Care. Child Abuse \& Neglect: The International Journal, 36(10), 722-731.

Gabel (2009). The growing divide: the marginalisation of young Roma children in Bulgaria. International Journal of Social Welfare 2009, 18, 65-75

Gilbert R., Fluke J., O'Donnell M., Gonzalez-Izquierdo A., Brownell M., Gulliver P., Janson S., \& Sidebotham P. (2012a). Child maltreatment: variation in trends and policies in six developed countries. The Lancet 379, 9817, 758-772

Gudbrandsson B (2004). Children in institutions: prevention and alternative care Final Report. European Committee for Social Cohesion (CDCS). Strasbourg available from www.crin.org/docs/Children\%20in\%20Institutions.pdf accessed on 10/12/12

Harizanova, M (2007). Assessment of the reform of the child protection system in Bulgaria. Sofia, UNICEF.

HelpAge International and REPSSI (2011). Psychosocial care and support for older carers of orphaned and vulnerable children: Programming guidelines. REPSSI and HelpAge International, South Africa

Holiček R.A.M., Severinsson A.N. and Reichenberg, D. (2007). Child Care System Reform In South East Europe: A Sub-Regional Analysis Based On Country Assessments In Albania, Bulgaria, Fyr Macedonia, Serbia UNICEF CEE/CIS. Geneva available from http://www.unicef.org/ceecis/SEE_CC_multicountry.pdf accessed on 10/12/12

Kukova S. (2011). Roma Children at Risk and an "Unhitched" Government System. Obektiv Bulgarian Helsinki Commission downloaded on 18/07/2012 from http://old.bghelsinki.org/index.php?module=pages \&lg=en\&page=obektiv19101

Lazarov, L. and Kolev, D. (2012). Community Monitoring of Health Care Services in Veliko Turnovo and Pavlikeni Municipalities. Plovdiv, Bulgaria, Center Amalipe and Estarta. 
Markova G., Shilkret R. and Djalev L. (2008). Parents' attachment styles, mental representations, and institutionalization of children in Bulgaria. Infant Mental Health Journal $29,6,555-569$.

Marr CJ (undated). Assimilation Through Education: Indian Boarding Schools in the Pacific Northwest. University of Washington Libraries http://content.lib.washington.edu/aipnw/marr.html accessed on 11/12/2012

Midgley, J. \& Conley, A. (Eds.) (2010). Social Work and Social Development: Theories and Skills for Developmental Practice. New York: Oxford University Press.

Nelson, C. A., Zeanah, C. H., Fox, N. A., Marshall, P. J., Smyke, A. T. and Guthrie, D. (2007). Cognitive recovery in socially deprived young children: the Bucharest Early Intervention Project. Science 318(5858):1937-40.

O'Brien, C. and T. Chanturidze (2009). Assessment of Child Welfare Reform in Georgia: Final report. Oxford Policy Management, http://www.unicef.org/ceecis/Georgia_Child_Welfare_Assessment_report_2009.pdf accessed $10 / 12 / 12$

Overington C. (2008). Aboriginal foster generation exceeds Stolen Generations. The Australian November 24, 2008 downloaded 27/11/2012 from http://www.theaustralian.com.au/news/nation/more-aboriginal-children-in-care/storyeffrg6nf-1111118120107

Pearson R. and Kessler S. (1992). Use of rapid assessment procedures for evaluation by UNICEF in N. S. Scrimshaw and G. R. Gleason, (Eds) Rapid Assessment Procedures Qualitative Methodologies for Planning and Evaluation of Health Related Programmes. Boston, International Nutrition Foundation for Developing Countries.

Petrova-Dimitrova, N. (2009). Development of alternative services, including foster care, within the framework of reforming child protection system: Experience of Bulgaria. Geneva, Switzerland, UNICEF CEE/CISRO, available at http://www.unicef.org/ceecis/Development_of_Alternative_Services_Experience_of_Bulgari a_ENG.doc, [accessed 11/12/12]

Rechel, B, Blackburn, C, Spencer, N and Rechel, B (2009). Access to health care for Roma children in Central and Eastern Europe: findings from a qualitative study in Bulgaria. International Journal for Equity in Health, 8(24): 1475-9276

Reichenberg J and Nordemark A (2006). Evaluation of the Family Support and Foster Care Project and the Prevention of Infant Abandonment and De-institutionalization Project. Georgia, UNICEF CEE/CIS http://www.crin.org/docs/BCN - CP Evaluation - Georgia.pdf accessed $11 / 12 / 2012$ 
Rowe, W. A., Gavrilova, M., Velev, P., \& Shaw, T. (2009). Cutting the economic costs of prejudice: Microfinance services in Roma communities in Bulgaria. Enterprise Development and Microfinance, 20(3), 235-246.

Rutter, M., Beckett, C., Castle, J., Colvert, E., Kreppner, J., Mehta, M., Stevens, S. and Sonuga-Barke, E. (2007). Effects of profound early institutional deprivation: An overview of findings from a UK longitudinal study of Romanian adoptees. European Journal of Developmental Psychology 4,3, 332-350.

Saleebey, D. (1996). The Strengths Perspective in Social Work Practice: Extensions and Cautions. Social Work, 41(3), 296-305.

Sigal, J.J., Perry, J.C., Rossignol, M., \& Ouimet, M.C. (2003). Unwanted infants: Psychological and physical consequences of inadequate orphanage care 50 years later. American Journal of Orthopsychiatry, 73, 3-12.

Sinha V., Trocmé N., Fallon B., MacLaurin B., Fast E., Prokop S.T., et al (2011). Kiskisik Awasisak: Remember the Children. Understanding the Overrepresentation of First Nations Children in the Child Welfare System. Ontario: Assembly of First NationsSmith, D. (2010). 'Out of Care' 30 years on. Criminology and Criminal Justice, 10,2, 119-135.

Sofovic B, Kragulj J, Pop D (2012). Preventing the separation of children from their families in Bosnia and Herzegovina. Salisbury, Hope and Homes for Children http://www.crin.org/docs/Bosnia\%20Active\%20Family\%20Support\%20HHC.pdf accessed $11 / 12 / 2012$

Thorpe, D., Smith, D., Green, C. and Paley, J. (1980). Out of Care: The Community Support of Juvenile Offenders. London, George Allen and Unwin.

Tobis, D. (2000). Moving from residential institutions to community-based social services in Central and Eastern Europe and the Former Soviet Union. World Bank Publications.

Tolfree D. (1995). Roofs and Roots: The Care of Separated Children in the Developing World. London, Save the Children UK

Trocmé, N., Knoke, D., \& Blackstock, C. (2004). Pathways to overrepresentation of aboriginal children in Canada's child welfare system. Social Services Review 78,4, 577-601.

Tulip Foundation (2012). Trust in the Family Project. available online at http://www.tulipfoundation.net/id-783/Trust_in_the_Family_project.html accessed $11 / 12 / 12$

UAFA (2007). Trialling Gatekeeping Systems in Azerbaijan. Baku, UAFA .

UNICEF (2001). A Decade of Transition: Regional Monitoring Report No. 8. Florence, UNICEF International Research Centre. 
UNICEF (2007). Report From The Survey: Analysis of The Placement Of Children In Specialised Institutions In Ruse Region, Vidin and Pernik. Sofia, UNICEF.

UNICEF (2008). Child Care System Reform in South East Europe: A Sub-Regional Analysis Based On Country Assessments in Albania, Bulgaria, Fyr Macedonia, Serbia. Geneva, UNICEF CEE/CIS http://www.unicef.org/ceecis/SEE_CC_multicountry.pdf accessed 11/12/12.

UNICEF (2009). Analysis of the placement of children in specialised institutions in the Ruse region. Unpublished report, UNICEF Bulgaria

UNICEF (2010a). TransMONEE Database Florence. Florence, UNICEF International Research Centre.

UNICEF (2010b). At home or in a home? Formal care and adoption of children in Eastern Europe and Central Asia. Geneva, UNICEF Regional Office for CEE/CIS.

UNICEF (2011). Selected Innovations and Lessons learned from UNICEF Programme Cooperation 2008. New York, UNICEF.

UNICEF (2012). TransMonEE 2012 Database. Geneva, UNICEF Regional Office for CEECIS.

UNDP (2005). Support to the Formulation of a National Programme for Improving the Living Conditions of Disadvantaged Ethnic Minorities in Urban Areas Sofia, UNDP http://www.undp.bg/uploads/documents/1498_665_en.pdf accessed 12/04/2013

Van ljzendoorn MH, Luijk MPCM, Juffer F (2008). IQ of children growing up in children's homes: A meta-analysis on IQ delays in orphanages. Merrill-Palmer Quarterly 54,3, 341-356.

Volpi E., Tarkhan-Mouravi G. and Sumbadze, N. (2006). Evaluation of child protection projects in Georgia. Tbilisi, UNICEF http://www.crin.org/docs/CP\%20reform\%20assessment\%20Georgia.pdf last accessed $12 / 12 / 12$

Vozniuk, A.M., Taseev, V.B., Smoliakov, Yu. M. (1999). How the Identification and Placement of Orphans and Children left without Parental Care has been Resolved in the Samara Region. In UNICEF and the Department for the Affairs of the Family, Women, Children and Youth, Ministry of Labor and Social Development, State Policy: The Experience of the Regions of Russia in the Provision of Social Protection to Children and Families. Moscow, UNICEF and the Ministry of Labor and Social Development.

Ward E. (2006). Placement Analysis for Children Resident in DMSGD, DOVLRGD "Nezabravka" and DOVLRGD "Nadezhda", Stara Zagora. Stara Zagora, ARK.

White Bison (2010). Apologies Time Line: A summary of some important apologies and reconciliations from 1950 to the present. Colorado Springs, White Bison 
http://www.whitebison.org/boarding-school-apology/docs/ApologiesTimeLine.pdf accessed on $11 / 12 / 2012$

Windsor, J., Glaze, L. E., \& Koga, S. F. (2007). Language acquisition with limited input: Romanian institutions and foster care. Journal of Speech, Language, and Hearing Research, 50, 1365-1381.

World Bank (2010). World Bank Involvement in Roma Issues http://siteresources.worldbank.org/INTROMA/Resources/Roma_at_a_Glance.pdf accessed $10 / 12 / 12$

Zeanah, C. H., A. T. Smyke, and L. D. Settles. (2006). Orphanages as a developmental context for early childhood. in K. McCartney and D. Phillips, editors. Blackwell handbook of early childhood development pp 224-254. Malden Massachusetts, Blackwell.

Zelinsky, T. (2011). Microfinance: An Alternative Tool for Alleviating Roma Poverty in the Marginalized Regions. Sociologia - Slovak Sociological Review 43,1, 57-88. 


\section{Highlights}

- Poverty and social exclusion are major causes of infant institutionalisation

- We outline a social development model

- Examples of social development practices in gatekeeping are provided

- National gatekeeping systems should consider using a social development model 